\title{
The research and practice of computer innovation ability of college students in TPACK frame Han Zhiying
}

Jilin huaqiao foreign languages institute, Changchun 130117, China;

$$
\text { 24921174@qq.com }
$$

\begin{abstract}
Computer innovation ability to promote technological innovation in the field of the information age has an important role, promoting college students' computer practice innovation ability has become the important mission of basic computer education in university. This paper puts forward the "design driving innovation" computer practice teaching mode, and from multiple aspects elaborated the TPACK support for the teaching mode reform, for colleges and universities to explore the characteristic and practical computing new paths for cultivating the innovation to provide certain theoretical and practical reference.
\end{abstract}

Key words: TPACK; computer innovation ability ; design driving innovation

\section{Introduction}

In the information age, the application of computers permeates almost every field of economic society. The education public computer is the foundation for fostering innovation in the information age. The ability to innovate plays an important role in promoting technological innovation in all areas. The training of students' practical innovation ability has become a strategic task in the current university computer education. At the same time, the education informatization deeply affects the education teaching in colleges and universities, teachers only enrich their own knowledge of subject content, the teaching method of knowledge and technology knowledge, and all organic integration, to have the ability to cultivate innovative talents. In this paper, on the basis of introducing the TPACK knowledge framework, combining with the computer curriculum teaching practice, build the "design drive innovation" practice teaching mode, to promote the teaching model reform research has certain reference significance.

\section{The present investigation and analysis of the present situation of computer practice innovation in college students}

With the development of China's economy entering a new normal, innovation has risen to the height of the national strategy of the overall situation. Xi jinping stressed that to implement the strategy of innovation-driven development is to promote all-round innovation at the core of scientific and technological innovation. The science and technology innovation and innovation in every field of the information age cannot leave the computer and information network technology, all walks of life requires a large number of talents with innovative spirit and innovative ability. College students are a force of informationization innovation. They are active and innovative and have strong innovation needs. However, the lack of guidance on rational innovation and scientific innovation in some computer courses in universities failed to create a free and relaxed atmosphere of innovation. There is a gap between the innovative education environment and the innovation demand of students. Therefore, in the current economic situation, from the transformation of traditional industries to high-tech, college education of the students failed to fully meet the demand of economic and social innovation. Some of the graduates in the specific problems in the work, the sensitivity of the lack of information, lack of information innovation consciousness, even consider using computer to solve the problem, it is hard to learned the flexible use of information technology, is difficult to breakthrough and innovative solutions to problems.. 


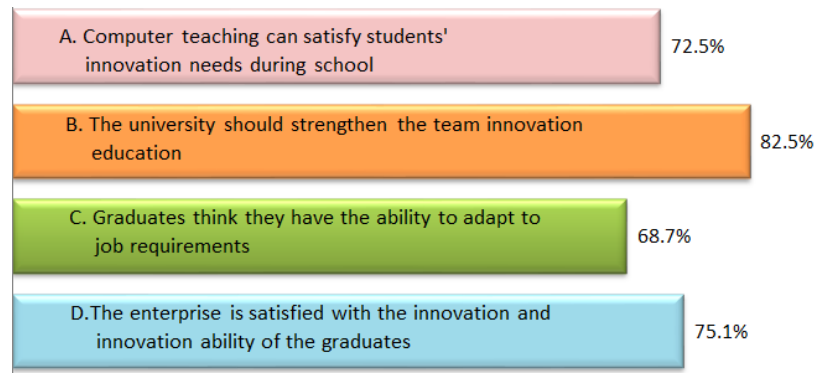

The author and the research team have been studying Jilin huaqiao foreign languages institute as a research institute. The survey was conducted on the satisfaction of computer innovation in the students, graduates and the working enterprises, take back 268 valid questionnaires. From the statistical results of the questionnaire, we can find the significant difference between students' innovation ability and social innovation demand. It is important that colleges and universities step up efforts to improve students' computer innovation ability as the current important task.

\section{The reform of teaching mode based on innovation ability under the framework of TPACK}

\subsection{The basic theory of TPACK}

TPACK (Technological Pedagogical Content Knowledge) the integration of technology knowledge of the subject teaching, put forward by American scholars . The TPACK framework consists of three core elements: knowledge of subject content, pedagogical knowledge, and technical knowledge ; Four composite elements: the discipline teaching content knowledge (PCK), integrated technology of knowledge (TCK), integrated technology of pedagogical knowledge (TPK), integrated technical subject teaching knowledge (TPACK). The research on TPACK will improve teachers' ability to master and use information technology. Teachers' TPACK ability is a prerequisite for teachers in the information age, which is a prerequisite for the achievement of students' computer practice.

\subsection{The practice teaching mode of "design driving innovation" is proposed}

Design is a creative activity that aims to improve the value of human life. It must have a strong driving force for innovation. In order to improve college students' innovation ability of computer practice, research group in the current practice teaching model based on innovation and development, put forward the concept of "design driving innovation", the computer innovation education up to the rational level.

The implementation process of "design driving innovation": at the beginning of the course, the students form a team and determine the theme goals of the comprehensive design of the team. Course in the learning process, students in the teachers' guidance, independent research, collecting materials, cooperate with online and offline teaching, and apply what they have learned to design continuously, gradually achieve design work in the form of team work; At the end of the course, the team completed the design. Courses around the whole process of design and innovation works, in all aspects of computer teaching process, each link into the "design" and "innovation", and firmly establish a students' innovative thinking, improve students' ability of innovation and teamwork in all aspects.

\subsection{TPACK supports the practice of "design driving innovation"}

(1) PCK level

The PCK refers to the subject teaching knowledge, and emphasizes the deep integration of teaching content and pedagogy. The practice teaching mode of "design driving innovation" is different from the traditional teaching mode of knowledge teaching, and the higher requirements for teachers are put forward. "Design driving innovation" requires a comprehensive design assignment at the beginning of the course, and the students work together with the teachers to work out the design goals. In the process of teaching, the teaching aim of every class is not pure is to make the students master 
knowledge, but to allow students to apply knowledge to continuously collected his material design, through the gradual accumulation, at the end of the course team to successfully accomplish the design goals, a new design work output. In this kind of teaching mode, the teacher must spend the work on the teaching design, each teaching link should pay attention to the guidance inspire the learner, cultivate their practical innovation ability. At the same time, because each team design theme is different, teachers to guide students in the personalized learning, the curriculum knowledge to achieve mastery through a comprehensive, flexible use in their own integrated design, so as to achieve good teaching results. In this kind of teaching mode, students are listening with the design requirements, stimulating the students' curiosity and improving the inner drive of the students. But this is a higher requirement for teachers, who have to grasp the content of the course, capture the essence and control the content of the course. Used in the teaching practice teaching case to from a traditional basic, confirmatory experiments, to give priority to with comprehensive, designing experiments, to everywhere guide students to independent innovation.

\section{(2) TCK level}

The TCK is the teaching application of integrated technology, which emphasizes the deep integration of information technology and curriculum knowledge teaching. In the practice teaching mode of "design driving innovation", the presentation of teaching content must not be dictated by single class. First, the teaching content is presented in an intuitive, visual and vivid way to improve the students' learning effect and stimulate their creative potential. Second, the students in the process of its design goals, learning demand is likely to be a lot of, by leaps and bounds, personalized, the classroom to teach the teaching contents are too limited. College computer teachers to raise their information literacy, therefore, to master the advanced education technology and information technology, the technology effectively integrate into specific subject content, and flexible to use in class, the teaching process. Through teaching, teachers form a comprehensive teaching resource package that matches the innovative teaching pattern, including: Different levels of stratified teaching cases; A series of microlectures, which are carefully crafted by teachers. Through the daily teaching and skill competition, the students' good design works are accumulated. These resources placed in real-time network teaching platform sharing, at the same time cooperate with the authority of the Mooc platform, allowing students to break the limit of time and space for personalized learning and independent innovation. This paper makes statistics on the application of network resources in two teaching modes.

Two kinds of practice teaching mode network resource utilization ratio comparison

\begin{tabular}{|c|c|c|c|c|}
\hline $\begin{array}{c}\text { Practice teaching } \\
\text { mode }\end{array}$ & $\begin{array}{c}\text { Hierarchical } \\
\text { case library }\end{array}$ & $\begin{array}{c}\text { Series } \\
\text { micro } \\
\text { class }\end{array}$ & $\begin{array}{c}\text { Excellent } \\
\text { design library }\end{array}$ & Mooc \\
\hline $\begin{array}{c}\text { Traditional } \\
\text { teaching mode }\end{array}$ & $53.4 \%$ & $61.5 \%$ & $73.4 \%$ & $45.6 \%$ \\
\hline $\begin{array}{c}\text { Design driving } \\
\text { innovation mode }\end{array}$ & $76.8 \%$ & $80.2 \%$ & $92.7 \%$ & $67.8 \%$ \\
\hline
\end{tabular}

(3)TPK level

The TPK refers to the application of the teaching method of integrated technology, which emphasizes the deep integration of information technology and teaching methodology. In the practice teaching mode of "design driving innovation", the learner begins with real questions, and studies the design of innovative products. Practice and practical principle should be emphasized in classroom teaching. Appropriate application of information technology, new media technology is conducive to the teachers and students together create vivid teaching situation, under the technical support team to make personalized learning effect is more outstanding, the use of technology to timely and real-time guidance, learners can make learners more efficiently to solve the practical problems through practice. In this kind of heuristic teaching and inquiry teaching mode of "design driving innovation", widen the 
road to the research of teaching information technology, technology can make the abstract, stationary, boring teaching becomes an novel, digital, three-dimensional, dynamic, vivid, inevitable coruscate gives more teaching method on the basis of vigor and vitality.

\section{(4) TPACK level}

TPACK refers to the comprehensive integration technology, teaching method and course content, but is not a simple combination of these three knowledge or overlay, but emphasis on technology and the course content and teaching method deeply, organic integration. In the practice teaching mode of "design driving innovation", the computer teacher to apply the concept of TPACK into computer course teaching, through the exploration and practice, constantly enrich and improve the TPACK. " design driving innovation " mode advocated in essence is based on the study, from the team selected topic, the multi-channel research, creative design, collecting materials, in the process of course gradually achieve design goals, until finally completed innovation works, each link is inseparable from the teachers' scientific guidance, teacher's TPACK knowledge level moment affects the teaching effect. The relationship between technology, pedagogy and subject matter is often interactive and dynamic. Will students team final design novel, unique and valuable product, to see whether the teachers could technology subject, teaching method and the integration of knowledge flexibly applied in teaching and learning, communication and collaboration between students and teachers, the creation process TPACK in dynamically coordinate teaching and learning all the time, every innovation production is closely related with the developing of TPACK. TPACK's best support for "design driving innovation" relies on the cognitive flexibility of each teacher to explore and explore in the combination and intersection of three kinds of knowledge.

\section{Conclusion}

\section{"Design drives innovation" practice teaching mode}

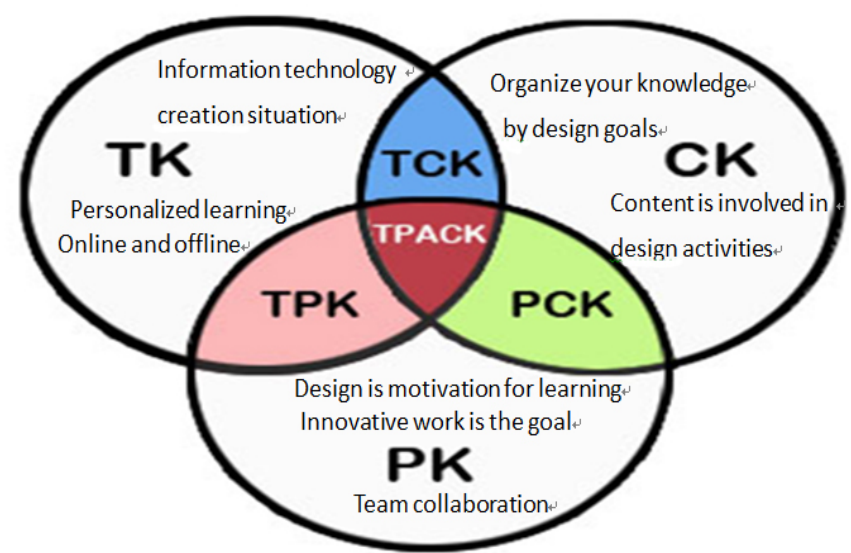

The new teaching model of "design driving innovation" offers new ideas for the reform of computer practice teaching. Its implementation will help improve the internal driving force of students' innovation and improve the flexibility, independence and creativity of students in the use of information technology solutions. The teaching effect of this kind of teaching is closely related to the fusion of technology, pedagogy and subject content. Under the framework of TPACK, the study of "design driving innovation" will provide a good foundation for students to use computer and information technology to practice innovation. Similarly, the study of TPACK in the process of "design driving innovation" must have a positive effect on the development and improvement of TPACK. In this paper, the research to improve the students' knowledge of using computer to solve practical problems and the ability to innovate, has positive significance to innovative talent training, has certain promotion value in the colleges and universities. 


\section{Acknowledgments}

This work was financially supported by Jilin province research on teaching reform of higher education project "The research and practice of computer practical and innovation ability of college students" .

\section{References}

[1] Wu huanqing, Yu shengquan. TPACK construction and applied research [J]. China electrochemical education 2014 (9).

[2] Roexin, $\mathrm{Wu}$ xiuyuan. The transformation of expert teacher training mode in TPACK view [J]. Modern education technology, 2013 (7)

[3]Long daya, Li jing. The research of computer experimental teaching and innovation [J]. Education research and experiment 2009 (7)

[4] Han zhiying. The application and research of multi-level hybrid teaching mode in computer teaching [J]. Journal of international studies, 2016 (4). 